\title{
Clinical significance of survivin and vascular endothelial growth factor mRNA detection in the peripheral whole blood of breast cancer patients
}

\author{
S. WANG, J. XU, Q. ZHANG* \\ Key Laboratory of Carcinogenesis and Translational Research (Ministry of Education), Department of Clinical Laboratory, Peking University \\ School of Oncology, Beijing Cancer Hospital \& Institute, Beijing 100142, China
}

*Correspondence: $z h q y \_208 @ 163 . c o m$

Received April 30, 2014 / Accepted August 17, 2015

\begin{abstract}
Survivin and vascular endothelial growth factor (VEGF) have been reported to overexpress in various human cancer tissues and peripheral blood, but have rarely been studied in the whole blood of breast cancer patients. So we want to investigate the mRNA expression of survivin and VEGF in whole blood of patients with breast cancer and explore the value of these two factors as biomarkers for possible early detection. Levels of survivin and VEGF mRNA expression in the whole blood of 43 early stage breast cancer patients and 25 normal controls were detected by qRT-PCR and the receiver operating characteristic (ROC) curve for each factor was constructed. As a result, the levels of suvivin and VEGF mRNA in breast cancer patients were 2.24 and 2.92 folds compared to normal controls, respectively and the difference was significant $(\mathrm{P}=0.0003$ and $\mathrm{P}<0.0001$, respectively). The cutoff value for differentiating breast cancer patients and normal people was $8.081 \times 10-3$ for survivin and $13.23 \times 10$-3 for VEGF. At the cutoff value, the area under ROC curve (AUC) for survivin was 0.7674 , the sensitivity and specificity were $83.72 \%$ and $64 \%$, respectively; For VEGF, it was 0.9163 , the sensitivity and specificity were $93.02 \%$ and $88 \%$, respectively. When combined the two factors, the AUC was 0.8981 , the sensitivity and specificity reached to $95.35 \%$ and $84 \%$, respectively. Furthermore we found that there was a significant correlation between survivin and VEGF mRNA ( $r=0.3970, p=0.0084)$. No significant difference was found between the expression levels of these two factors and the clinical pathological data. Thus, we came to a conclusion that it was a convenient and sensitive method to detect survivin and VEGF mRNA in the whole blood using qRT-PCR, and these two factors could be useful tumor biomarkers for early detection of breast cancer.
\end{abstract}

Key words: breast cancer, survivin, vascular endothelial growth factor, whole blood, real-time PCR

Breast cancer is the most common and the leading cause of cancer death in women, accounting for $14.5 \%$ of the total cancer deaths. In recent years, although the mortality rates of breast cancer are decreasing, the incidence is still increasing [1]. This owes to the improvement of health awareness and early diagnostic methods such as regular self-examination, periodic mammography checkups, ultrasonography and tissue biopsy assay. However, these still have many drawbacks. For example, small tumors may escape from the detector; Biopsy can only be used on patients with suspicious imaging examination, and it is unpractical to be applied in routine screening for disease recurrence and response to treatments. So it is still urgent to find an easy, sensitive, accurate and noninvasive way to follow up the tumor activity.

Survivin, also called baculoviral inhibitor of apoptosis repeat containing 5 (BIRC5), is a member of the inhibitor of apoptosis (IAP) family [2]. Biologically, it plays critical roles in promoting cell proliferation and preventing apoptosis [3]. Characteristically, survivin mRNA is selectively and abundantly expressed in fetal tissues and most human tumors, but is rarely found in normal differentiated tissues [4]. Numerous studies have suggested that increased survivin expression is correlated with advanced disease, frequent recurrence, short survival and resistance to therapy [5-7], thus, it might be an ideal tumor marker in the diagnosis and prognosis of most tumors including breast cancer $[8,9]$.

Vascular endothelial growth factor(VEGF) is a glycoprotein which is essential for the development of the tumor angiogenesis $[10,11]$, stimulating tumor metastasis, proliferation, invasion, and endothelial cell migration [12]. As previously reported, breast cancer was a typical angiogenesis-dependent tumor,which spreads easily through bloodstream, even in early 
stage [13], and the expression of VEGF directly led to poor prognosis and the tendency of metastasis [14]. What's more, it can also be related to shorter relapse-free survival in earlystage breast cancer patients [15].

For the detection of survivin and VEGF, IHC or PCR-based methods were mostly apllied in the tumor tissues [17-19], and ELISA method was frequently used in peripheral blood. However, the change of mRNA level usually occurs earlier than protein level [22], and qRT-PCR which combines the high efficiency of PCR and the high sensitivity and accurate quantification of spectral analysis has been proved to be a sensitive and convenient method [23]. So in the present study,

Table 1. Characteristics of patients $(n=43)$ and controls $(n=25)$

\begin{tabular}{|c|c|c|}
\hline Parameters & breast cancer patients & normal controls \\
\hline number of cases & 43 & 25 \\
\hline age & & \\
\hline median (range) & $50(26-71)$ & $36(20-69)$ \\
\hline$\leq 50$ & 20 & 17 \\
\hline$>50$ & 23 & 8 \\
\hline \multicolumn{3}{|l|}{ Tumor size $(\mathrm{mm})$} \\
\hline$\leq 20$ & 21 & \\
\hline$>20$ & 22 & \\
\hline \multicolumn{3}{|l|}{ Lymph nodes } \\
\hline Positive & 15 & \\
\hline Negative & 28 & \\
\hline \multicolumn{3}{|l|}{ Histologic Grade } \\
\hline $0 / \mathrm{I}$ & 8 & \\
\hline II & 18 & \\
\hline III & 12 & \\
\hline Unknown & 5 & \\
\hline \multicolumn{3}{|l|}{ Clinical stages } \\
\hline I & 20 & \\
\hline II & 23 & \\
\hline \multicolumn{3}{|l|}{ ER status } \\
\hline Positive & 27 & \\
\hline Negative & 15 & \\
\hline Unknown & 1 & \\
\hline \multicolumn{3}{|l|}{ PR status } \\
\hline Positive & 24 & \\
\hline Negative & 18 & \\
\hline Unknown & 1 & \\
\hline \multicolumn{3}{|l|}{ HER2 status } \\
\hline Positive & 33 & \\
\hline Negative & 9 & \\
\hline Unknown & 1 & \\
\hline \multicolumn{3}{|l|}{ Ki-67 } \\
\hline Positive & 18 & \\
\hline Negative & 24 & \\
\hline Unknown & 1 & \\
\hline \multicolumn{3}{|l|}{ Menopausal status } \\
\hline Premenopause & 21 & \\
\hline Postmenopause & 22 & \\
\hline
\end{tabular}

we investigated the mRNA expression of survivin and VEGF in the whole blood of early stage breast cancer patients using quantitative real-time PCR and their diagnostic potential through ROC curve. Besides, we examined the relationship between survivin and VEGF, and their correlation with clinical pathological factors.

\section{Patients and methods}

Patients. Forty-three female patients with early stage breast cancer (stage I and stage II) were consecutively collected at Peking University Cancer Hospital (Beijing, China). All 43 patients had been histopathologically confirmed as breast cancer and received no treatment. The median age of the patients was 50 (26-71). Twenty-five healthy people (median age 36, 20-69) were used as normal control. For all patients the tumor size, histological grade, clinical stage, involvement of lymph nodes, ER, PR and HER-2 status were obtained. This study was approved by the Institutional Ethics Committee of Peking University and informed consent was obtained for the use of all samples. Characteristics of the patients and controls were shown in Table 1.

Total RNA extraction and cDNA synthesis. The peripheral blood samples were collected in EDTA-K2 anticoagulation tubes. Total RNA was extracted from breast cell line MCF-7 and whole blood ( all blood components, including blood cells and plasma) using Trizol in accordance with the manufacturer's instructions. Each $300 \mu$ whole blood was added with $1 \mathrm{ml}$ Trizol (Invitrogen). Its integrity was assayed with $1 \%$ agarose gel electrophoresis, and the purity and quality were assessed by Thermo Scientific NanoDrop2000. Complementary DNA was synthesized from $1 \mu \mathrm{g}$ of total RNA using commercially available $5^{\star}$ five in all reverse transcription kit(abm company) according to the recommended protocol.

Quantitative Real-time PCR. Primers for survivin and $\beta$-actin were designed using Premier 5.0 software, and primers were located at the junction between two exons to avoid amplification of contaminating genomic DNA. Primers for VEGF were from the literature [16].

The oligonucleotides were synthesized by sinogenomax company (Beijing) and their sequences were listed in Table 2. The ABI 7500FAST Real-Time PCR Detection System was used for real-time PCR. PCR reaction was performed in a total

Table 2. Primers of $\beta$-actin, Survivin and VEGF used for real-time PCR

\begin{tabular}{|c|c|c|c|}
\hline Gene name & Primer & Sequence(5-3') & $\begin{array}{l}\text { Product } \\
\text { size (bp) }\end{array}$ \\
\hline \multirow[t]{2}{*}{ Survivin } & Forward & AGGACCACCGCATCTCTACA & 187 \\
\hline & Reverse & TGTTCCTCTATGGGGTCGTCA & \\
\hline \multirow[t]{2}{*}{ VEGF } & Forward & GAGTACATCTTCAAGCCATCCTG & 204 \\
\hline & Reverse & TGCTCTATCTTTCTTTGGTCTGC & \\
\hline \multirow[t]{2}{*}{$\beta$-actin } & Forward & GGACTTCGAGCAAGAGATGG & 234 \\
\hline & Reverse & AGCACTGTGTTGGCGTACAG & \\
\hline
\end{tabular}


volume of $10 \mu \mathrm{l}$, including $1 \mu \mathrm{l} \mathrm{cDNA}, 5 \mu \mathrm{l}$ FastStart Universal SYBR Green MasterMix (ROX) (Roche), $0.1 \mu$ l forward primer, $0.1 \mu \mathrm{l}$ reverse primer $(10 \mu \mathrm{M})$ and $3.8 \mu \mathrm{l} \mathrm{H}_{2} \mathrm{O}$. The reaction program began with an initial denaturation step of $10 \mathrm{~min}$ at $95^{\circ} \mathrm{C}$, followed by 42 cycles at $95^{\circ} \mathrm{C}$ for $30 \mathrm{~s}$ and $58^{\circ} \mathrm{C}$ for $20 \mathrm{~s}, 72^{\circ} \mathrm{C}$ for $20 \mathrm{~s}$. The primer efficiency for $\beta$-actin, survivin and VEGF were $93.5 \%, 95.2 \%$ and $92.1 \%$, respectively. For all samples, positive, negative and no template controls were performed. To ensure the reproducibility of results, all genes were tested in triplicate and the real-time PCR analyses were performed blind for the identity and clinical outcome of the patients.

Calculations were made with the use of the comparative CT $\left(2^{-\Delta \Delta C T}\right)$ method. The mRNA amounts of a target gene were normalized to $\beta$-actin, and breast cell line MCF-7 was used as calibrator. $\Delta \mathrm{CT}=\mathrm{Ct}$ (Target) $-\mathrm{Ct}$ (Reference), $\Delta \Delta \mathrm{CT}=\Delta \mathrm{CT}$ (Sample) $-\Delta \mathrm{CT}$ (Calibrator). If the mean Ct (threshold cycle)

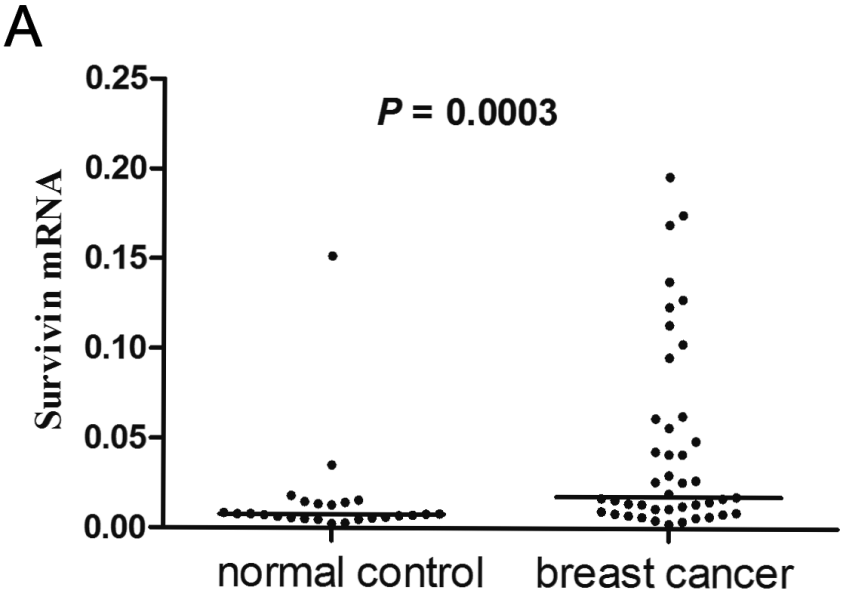

B

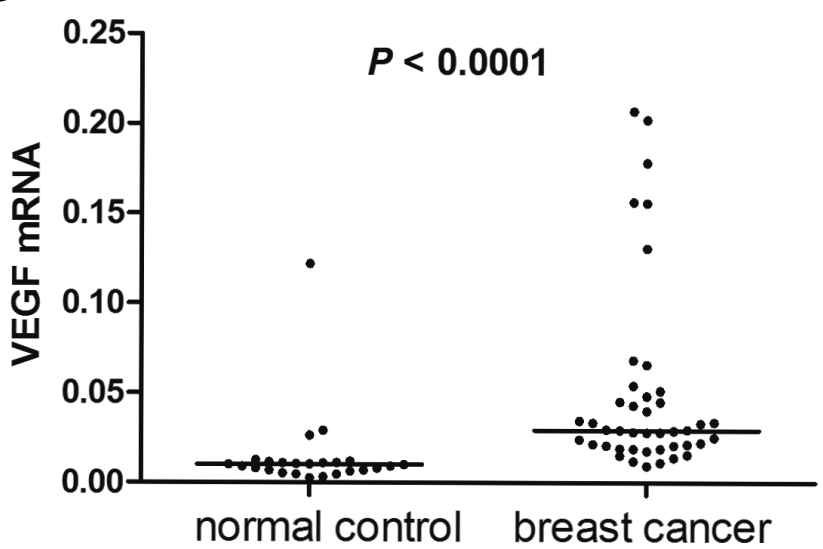

Figure 1. Whole blood levels of survivin(A) and $\operatorname{VEGF(B)~mRNA~in~}$ breast cancer patients $(n=43)$ and normal controls $(n=25)$. Each dot represents the average of three repeated assays of an individual and the horizontal lines represent the median values. VEGF, vascular endothelial growth factor.
A

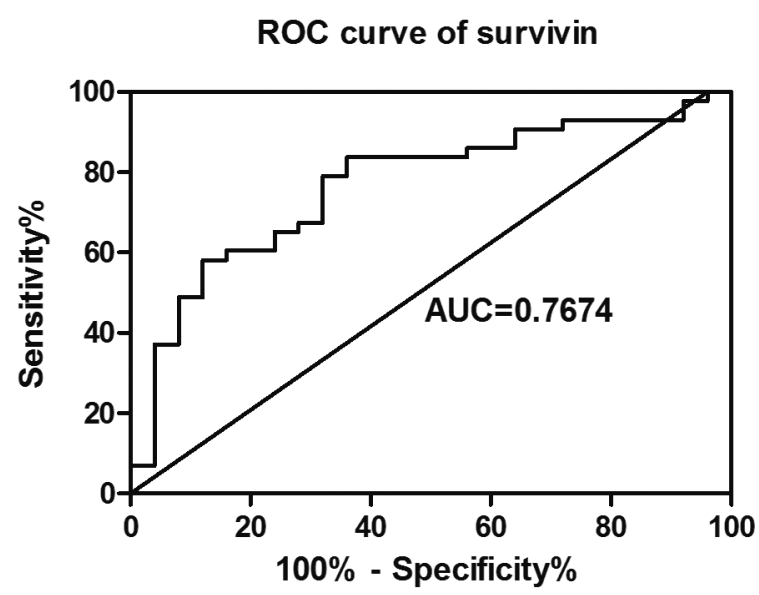

B

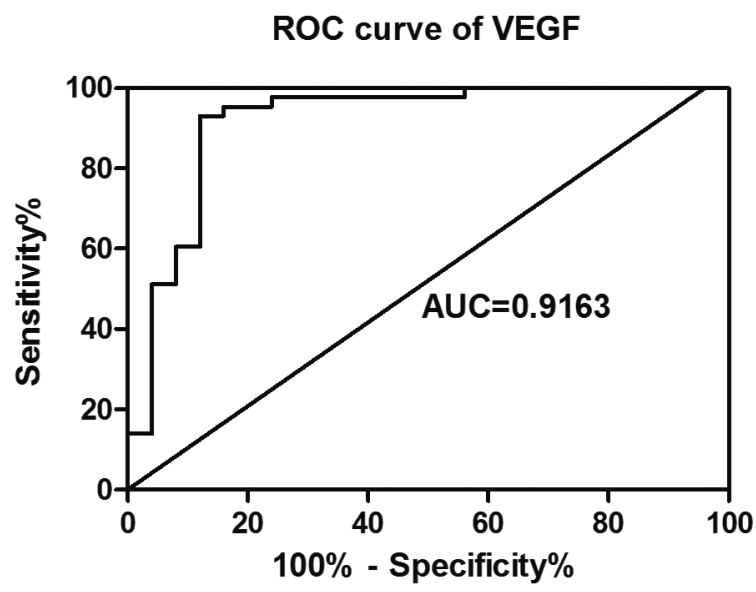

C

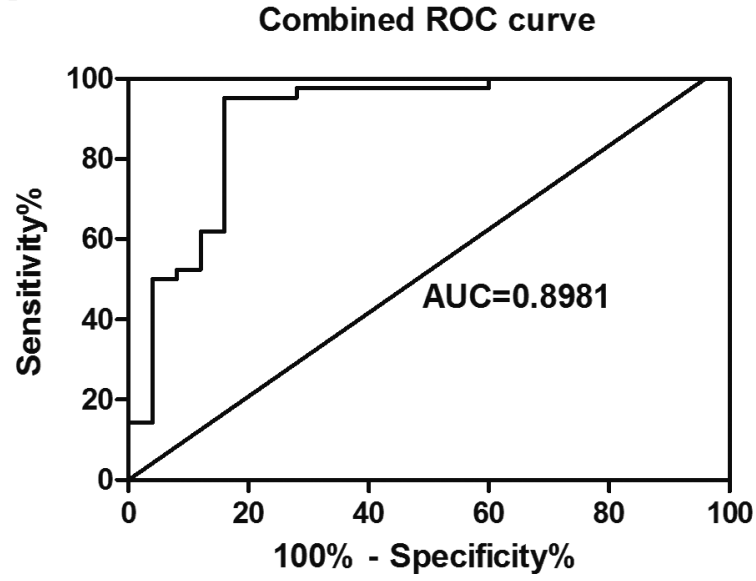

Figure 2. Receiver-operating characteristic (ROC) curves were generated to compare breast cancer patients and normal controls for Survivin(A), VEGF mRNA(B) and Combined (C). The sensitivity, specificity, PPV and NPV for survivin was $83.72 \%, 64 \%, 80 \%$ and $69.6 \%$, respectively; for VEGF was $\mathbf{9 3 . 0 2 \%}, \mathbf{8 8} \%, 93 \%$ and $88 \%$, respectively; The sensitivity and specificity of combination both survivin and VEGF was $95.35 \%$ and $84 \%$, respectively. 


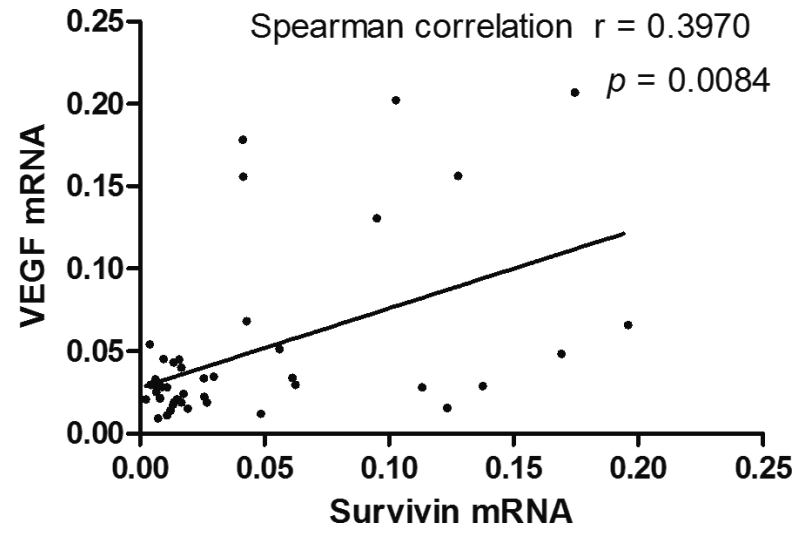

Figure 3. Correlation between Survivin and VEGF mRNA levels in breast cancer patients. Each dot represents a patient, $n=43$.

Table 3. Correlation between Survivin and VEGF mRNA positive rates and clinicopathologic parameters in breast cancer patients.

\begin{tabular}{|c|c|c|c|c|}
\hline Parameters & $\begin{array}{c}\text { Survivin } \\
\text { mRNA(\%) }\end{array}$ & $P$ value & $\begin{array}{c}\text { VEGF } \\
\text { mRNA(\%) }\end{array}$ & $P$ value \\
\hline age & & 0.303 & & 1 \\
\hline$\leq 50$ & $15 / 20(75)$ & & $19 / 20(95)$ & \\
\hline$>50$ & $21 / 23(91.3)$ & & $21 / 23(91.3)$ & \\
\hline Tumor size (mm) & & 1 & & 0.215 \\
\hline$\leq 20$ & $18 / 21(85.7)$ & & $18 / 21(85.7)$ & \\
\hline$>20$ & $18 / 22(81.8)$ & & $22 / 22(100)$ & \\
\hline Lymph nodes & & 1 & & 0.492 \\
\hline Positive & $13 / 15(86.7)$ & & $15 / 15(100)$ & \\
\hline Negative & $23 / 28(82.1)$ & & $25 / 28(89.3)$ & \\
\hline Histologic Grade & & 1 & & 0.563 \\
\hline 0/I/II & $21 / 26(80.8)$ & & $23 / 26(88.5)$ & \\
\hline III & $10 / 12(83.3)$ & & $12 / 12(100)$ & \\
\hline Unknown & 5 & & 5 & \\
\hline Clinical stages & & 1 & & 0.185 \\
\hline I & $17 / 20(85)$ & & $17 / 20(85)$ & \\
\hline II & $19 / 23(82.6)$ & & $23 / 23(100)$ & \\
\hline ER status & & 1 & & 1 \\
\hline Positive & $23 / 27(85.2)$ & & $26 / 27(96.3)$ & \\
\hline Negative & $13 / 15(86.7)$ & & $14 / 15(93.3)$ & \\
\hline Unknown & 1 & & 1 & \\
\hline PR status & & 0.949 & & 0.34 \\
\hline Positive & $20 / 24(83.3)$ & & $19 / 24(79.1)$ & \\
\hline Negative & $16 / 18(88.9)$ & & $17 / 18(94.4)$ & \\
\hline Unknown & 1 & & 1 & \\
\hline HER2 status & & 0.044 & & 0.211 \\
\hline Positive & 29/33 (87.9) & & $32 / 33(97)$ & \\
\hline Negative & $5 / 9(55.5)$ & & $7 / 9(77.8)$ & \\
\hline Unknown & 1 & & 1 & \\
\hline Ki-67 status & & 1 & & 0.341 \\
\hline Positive & $15 / 18(83.3)$ & & $18 / 18(100)$ & \\
\hline Negative & $21 / 24(87.5)$ & & $21 / 24(87.5)$ & \\
\hline Unknown & 1 & & 1 & \\
\hline Menopausal status & & 0.372 & & 1 \\
\hline Premenopause & $16 / 21(76.2)$ & & $20 / 21(95.2)$ & \\
\hline Postmenopause & 20/22 (90.9) & & $20 / 22(90.9)$ & \\
\hline
\end{tabular}

value for a gene of interest was $\geq 38$, the gene expression was considered to be undetectable.

Statistical analysis. All data were analyzed using the SPSS 18.0 software. Mann-Whitney test was used to compare the two gene mRNA levels in blood between groups. A receiver operating characteristic curve (ROC) was constructed to evaluate the diagnostic performance of blood levels of the two target gene mRNAs, and the area under the curve (AUC) was measured. The best cut-off value was determined using the Youden index. The correlation between the positive rates of the two gene mRNA and patient clinicopathologic parameters was assessed using Chi-square analysis or Fisher's exact test. The Spearman rank correlation coefficient was used to assess the correlation between survivin and VEGF mRNA level expression. A value of $\mathrm{P}<0.05$ was considered statistically significant.

\section{Results}

Expression levels of survivin and VEGF mRNA in whole blood of breast cancer patients. Representative amplification and melt curves were showed in Supplementary Fig. 1-6.

The expression of survivin and VEGF mRNA in whole blood of breast cancer patients was significantly higher than that of normal controls. [Survivin: 0.0175 (range, 0.00240.1960 ) vs. 0.0078 (range, $0.0024-0.1515)$ ( $\mathrm{P}=0.0003$ ); VEGF: 0.0292 (range, 0.0093-0.2069) vs. 0.0101(range, 0.0025-0.1221) $(\mathrm{P}<0.0001)$ ]. (Fig. 1A and Fig. 1B)

Diagnostic value of survivin and VEGF mRNA qRTPCR assay. According to the ROC curve, the optimum cut off values of survivin and VEGF mRNA levels for diagnosing breast cancer were 0.008081 and 0.01323 . The AUC for survivin was 0.7674 and for VEGF was 0.9163 (Fig. 2A and Fig. 2B). For distinguishing breast cancer patients from normal ones, survivin had a $83.72 \%$ sensitivity, and a $64 \%$ specificity, respectively. The sensitivity and specificity of VEGF were 93.02\% and $88 \%$ respectively. The PPV and NPV for survivin were $80 \%$ and $69.6 \%$; for VEGF , $93 \%$ and $88 \%$, respectively. When combined to the two factors, the AUC was 0.8981 , the sensitivity and specificity reached to $95.35 \%$ and $84 \%$, respectively (Fig. 2C).

Correlation between survivin and VEGF mRNA expression in whole blood of breast cancer patients. As shown in Fig. 3, Spearman's rank correlation was used to analyze the correlation between the whole blood levels of survivin and VEGF in breast cancer patients. The results indicated that the expression of survivin was found to be significantly correlated with the expression of VEGF $(r=0.3970 ; \mathrm{P}=0.0084)$.

Clinical correlation of survivin and VEGF mRNA levels in the cell fraction of peripheral blood. Relationship between the positive rates of survivin and VEGF mRNA and the clinicopathologic characteristics in breast cancer patients were shown in Table 3.

No significant difference was found between survivin and any of the clinical parameters, and the same results were found for VEGF. 
Table 4. Clinicopathologic parameters of each subgroup

\begin{tabular}{|c|c|c|c|c|c|c|c|c|c|c|c|c|c|c|c|c|c|c|c|c|}
\hline \multirow{2}{*}{$\begin{array}{l}\text { Groups } \\
\text { Survivin mRNA }\end{array}$} & \multicolumn{2}{|c|}{ age } & \multicolumn{2}{|c|}{$\begin{array}{l}\text { Histologic } \\
\text { Grade }\end{array}$} & \multicolumn{2}{|c|}{$\begin{array}{l}\text { Clinical } \\
\text { stages }\end{array}$} & \multicolumn{2}{|c|}{$\begin{array}{l}\text { Lymph } \\
\text { nodes }\end{array}$} & \multicolumn{2}{|c|}{$\begin{array}{c}\text { Tumor } \\
\text { size }(\mathrm{mm})\end{array}$} & \multicolumn{2}{|c|}{$\begin{array}{c}\text { ER } \\
\text { status }\end{array}$} & \multicolumn{2}{|c|}{$\begin{array}{c}\mathrm{PR} \\
\text { status }\end{array}$} & \multicolumn{2}{|c|}{$\begin{array}{l}\text { HER2 } \\
\text { status }\end{array}$} & \multicolumn{2}{|c|}{$\begin{array}{l}\mathrm{Ki}-67 \\
\text { status }\end{array}$} & \multicolumn{2}{|c|}{$\begin{array}{c}\text { Menopausal } \\
\text { status }\end{array}$} \\
\hline & $<50$ & $>=50$ & $\begin{array}{c}0 / \mathrm{I} / \\
\mathrm{II}\end{array}$ & III & $\mathrm{I}$ & II & + & - & $\leq 20$ & $>20$ & + & - & + & - & + & - & + & - & $\begin{array}{l}\text { Premeno- } \\
\text { pause }\end{array}$ & $\begin{array}{c}\text { Postmen- } \\
\text { opause }\end{array}$ \\
\hline$>0.15(n=3)$ & 1 & 2 & 2 & 1 & 2 & 1 & 2 & 1 & 2 & 1 & 0 & 3 & 0 & 3 & 2 & 1 & 2 & 1 & 1 & 2 \\
\hline $0.09-0.15(n=6)$ & 4 & 2 & 5 & 1 & 2 & 4 & 5 & 1 & 2 & 4 & 4 & 2 & 4 & 2 & 0 & 6 & 4 & 2 & 3 & 3 \\
\hline $0.04-0.09(n=7)$ & 2 & 5 & 6 & 1 & 4 & 3 & 4 & 3 & 5 & 2 & 2 & 5 & 3 & 4 & 0 & 6 & 6 & 1 & 2 & 5 \\
\hline$<0.04(\mathrm{n}=27)$ & 13 & 14 & 17 & 10 & 12 & 15 & 17 & 12 & 12 & 17 & 9 & 17 & 11 & 15 & 7 & 19 & 12 & 14 & 14 & 13 \\
\hline$P$ Value & \multicolumn{2}{|c|}{0.601} & \multicolumn{2}{|c|}{0.675} & \multicolumn{2}{|c|}{0.781} & \multicolumn{2}{|c|}{0.828} & \multicolumn{2}{|c|}{0.453} & \multicolumn{2}{|c|}{0.262} & \multicolumn{2}{|c|}{0.365} & \multicolumn{2}{|c|}{0.064} & \multicolumn{2}{|c|}{0.301} & \multicolumn{2}{|c|}{0.696} \\
\hline \multicolumn{21}{|l|}{ VEGF mRNA } \\
\hline$>0.1 \quad(\mathrm{n}=6)$ & 3 & 3 & 5 & 1 & 2 & 4 & 5 & 1 & 2 & 4 & 2 & 4 & 3 & 3 & 0 & 6 & 4 & 2 & 3 & 3 \\
\hline $0.04-0.1(n=8)$ & 2 & 6 & 5 & 3 & 4 & 4 & 4 & 4 & 5 & 3 & 1 & 7 & 2 & 6 & 2 & 6 & 4 & 4 & 3 & 5 \\
\hline$<0.04(\mathrm{n}=29)$ & 15 & 14 & 21 & 8 & 14 & 15 & 19 & 10 & 14 & 15 & 11 & 17 & 13 & 15 & 7 & 21 & 16 & 12 & 14 & 15 \\
\hline$P$ Value & \multicolumn{2}{|c|}{0.422} & \multicolumn{2}{|c|}{0.773} & \multicolumn{2}{|c|}{0.811} & \multicolumn{2}{|c|}{0.441} & \multicolumn{2}{|c|}{0.597} & \multicolumn{2}{|c|}{0.379} & \multicolumn{2}{|c|}{0.639} & \multicolumn{2}{|c|}{0.537} & \multicolumn{2}{|c|}{0.904} & \multicolumn{2}{|c|}{0.901} \\
\hline
\end{tabular}

“+”: positive

“-”: negative

The difference between clinicopathologic parameters of each subgroup. In Fig. $1 \mathrm{~A}$, we can see that the mRNA levels of survivin and VEGF in whole blood samples from the breast cancer patients varied within the group, so we further divided the data points into 4 subgroups for survivn $(<0.04,0.04-0.09$, $0.09-0.15,>0.15)$ and 3 subgroups for $\operatorname{VEGF}(<0.04,0.04-0.1$, $>0.1$ ). The clinicopathologic parameters of each subgroup were analyzed using Fisher's exact test, however, no significant difference was found.

\section{Discussion}

In the present study, we evaluated the clinical significance of qRT-PCR detection of survivin and VEGF mRNA in the peripheral blood of breast cancer patients. The results indicated that for diagnosis of breast cancer, the sensitivity and specificity of survivin was $83.72 \%$ and $64 \%$, of VEGF was $93.02 \%$ and $88 \%$.We also demonstrated that there was a positive correlation between levels of survivin and VEGF mRNA.

To the best of our knowledge, data about quantitative survivin and VEGF mRNA evaluation in the whole blood of breast cancer are still lacking. As we discussed in the last part of introduction, qRT-PCR which combines the high efficiency of PCR and the high sensitivity and accurate quantification of spectral analysis has been proved to be a sensitive and convenient method [23]. Real-time RT-PCR provides significantly greater specificity and sensitivity than ELISA or conventional RT-PCR [24].This assay was designed to use only SYBR Green, without any need for expensive hybridization probes. Since the tumor and whole environment of body can affect each other mutually, and the mRNA can also exist in the plasma and serum $[25,26]$, we try to evaluate the overall level of their expression in the whole blood to see if they can be used for early detection of tumors.

Survivin is an inhibitor of apoptosis protein (IAP) and is over expressed in a wide spectrum of tumors including breast cancer $[27,28]$. Considering of its differentiated expression between normal and cancerous tissues, it has become an attractive molecule for early detection and prognosis of breast cancer. And the diagnostic role of survivin has been widely confirmed in blood [16], urine [29], salivary [30], pleural effusion [31], and other body fluids.

This study indicates that survivin mRNA levels in whole blood has a potential for early detection of breast cancer. For the detection of survivin mRNA in PBMCs of breast cancer patients, Shen ChangXin et al reported a positive rate of $36.2 \%$ (34/94) using qRT-PCR [9], and the positive rate was $50.7 \%(34 / 67)$ in a study of Yie using RT-PCR ELISA method. And we then performed ELISA on 15 patients with BC using Human SURVIVIN ELISA Kit and Human VEGF ELISA Kit of BOSTER, only 2 samples were positive for survivin, and 13 for VEGF. However, the positive rate of the detection in whole blood using qRT-PCR came to $83.7 \%(36 / 43)$. It is obvious that this method is more sensitive for detecting survivin mRNA in the whole blood. In contrast with other published studies $[18,32]$, we didn't find significant difference between survivin mRNA and any of the clinical parameters. However, this is in accordance with some other reports. Nese Guney et al. reported that none of the clinical parameters analyzed were significantly correlated with the serum survivin concentrations, except for nodal involvement [33]; Shen ChangXin et al. demonstrated no correlation was found between survivin mRNA and tumor size and histologic grade [9].

Sources of increased survivin concentrations in peripheral blood from patients with cancer are not well known. Earlier studies indicated that survivin expression was barely expressed in normal tissues or blood cells [34, 35], so we hypothesise that the elevation of survivin mRNA in the peripheral blood may come from the circulating cancer cells or release of the tumor. 
The expression level of VEGF using plasma, serum, whole blood cells have been evaluated in many researches and some researchers recommended that serum or whole blood, but not plasma, should be used in evaluating VEGF in the circulation in cancer patients. [36, 37]. In breast cancer, recent literatures regarding clinical significance of circulating VEGF produced conflicting results. Some researchers found the correlation between a high concentration of VEGF, clinical stage,histological grade,and lymph nodes $[38,39]$. However, no significant correlation between VEGF and clinicopathological features was found in our study. Similar results were obtained by other authors. Granato and Paola found no correlation between VEGF concentrations and tumor size or metastasis to regional lymphnodes [40,41] and no relationship was found between VEGF levels and cancer stage [42]. Srabovic et al. showed no significant correlations between VEGF and tumor size, histological grade, and hormone receptor status [43]. What's more, Hodorowicz-Zaniewska D et al. also found no correlation between VEGF concentrations and any of the clinicopathological factors in breast cancer patients [21].

As for sources of increased VEGF concentrations in peripheral blood from patients with cancer are not known in detail. Earlier studies indicated that circulating VEGF can originate in cancer cells [44] and can be found in all blood cell types examined, including megakaryocytes, platelets, lymphocytes, granulocytes, and monocytes [45, 46]. Also, tumor-infiltrating inflammatory cells have been shown to express VEGF in several histological types of cancer $[47,48]$. Werther $\mathrm{K}$ et al indicated that circulating neutrophils and platelets contain considerable amounts of VEGF [49], and Petri Salven et al found that the VEGF content of comparable leukocyte and platelets was higher in cancer patients than in healthy controls [50], so both the number increase of leukocyte and platelets and the rise of VEGF concentration per cell unit may attribute to the elevated level of VEGF in peripheral blood. Though we still don't known the exact source of the elevated circulating VEGF, either from cancer cells or blood cells, they may both have a role in tumor angiogenesis and metastasis formation.

Earlier reports have shown that apoptosis inhibition is closely associated with angiogenesis in the occurrence, development, invasion, recurrence, and metastasis of tumors. VEGF was found to up-regulate the expression of survivin in cultured endothelial cells, higher expression of VEGF in tumor angiogenesis promotes and induces high expression of survivin, which then up-regulates other critical factors [51]. Similarly, survivin, through up regulation of VEGF, plays an essential role during glioma angiogenesis [52]. In this study, the expression of survivin was positively correlated with that of VEGF in whole blood of breast cancer patients $(r=0.3970$; $\mathrm{P}=0.0084$ ), which was in accordance with previous studies and indicated the inner links between these two factors.

In conclusion, both survivin and VEGF in the whole blood are potentially important biomarkers for early detection of breast cancer. The detection of their expression using qRT-PCR method described in this study is a sensitive and quantitative way. And there is a positive correlation between survivin and VEGF. However, the number of patients presently included was very small, so further studies conducted in larger scales were needed. Furthermore, follow-up observations in the study were not carried out and therefore the role of survivin and VEGF as prognostic factors in this group of patients cannot be described.

Supplementary information is available in the online version of the paper.

Acknowledgments: This work was supported by the National high technology research development plan(No. 2012AA02A504). We thank all the people and patients who participated in this study.

\section{References}

[1] SIEGEL R, NAISHADHAM D AND JEMAL A: Cancer statistics, 2013. CA: a cancer journal for clinicians 2013; 63: 11-30. http://dx.doi.org/10.3322/caac.21166

[2] AMBROSINI G, ADIDA C AND ALTIERI DC: A novel anti-apoptosis gene, survivin, expressed in cancer and lymphoma. 1997; Nat Med 3: 917-921. http://dx.doi.org/10.1038/ $\underline{\mathrm{nm} 0897-917}$

[3] ALTIERI DC: Targeted therapy by disabling crossroad signaling networks: the survivin paradigm. Mol Cancer Ther 2006; 5: 478-482. http://dx.doi.org/10.1158/1535-7163.MCT-05-0436

[4] DUFFY MJ, O'DONOVAN N, BRENNAN DJ, GALLAGHER WM AND RYAN BM: Survivin: a promising tumor biomarker. Cancer Lett 2009; 249: 49-60. http://dx.doi.org/10.1016/j. canlet.2006.12.020

[5] JHA K, SHUKLA M AND PANDEY M: Survivin expression and targeting in breast cancer. Surg Oncol 2012; 21: 125-131. http://dx.doi.org/10.1016/j.suronc.2011.01.001

[6] SPRENGER T, RODEL F, BEISSBARTH T, CONRADI LC, ROTHE H et al: Failure of downregulation of survivin following neoadjuvant radiochemotherapy in rectal cancer is associated with distant metastases and shortened survival. Clin Cancer Res 2011; 17: 1623-1631. http://dx.doi. org/10.1158/1078-0432.CCR-10-2592

[7] XI RC, SHENG YR, CHEN WH, SHENG L, GANG JJ et al: Expression of survivin and livin predicts early recurrence in non-muscle invasive bladder cancer. J Surg Oncol 2013; 107: 550-554. http://dx.doi.org/10.1002/jso.23272

[8] ADAMKOV M, HALASOVA E, KAJO K, MACHALEKOVA K, VYBOHOVA D et al: Survivin: a promising biomarker in breast carcinoma. Neoplasma 2010; 57:572-577. http://dx.doi. org/10.4149/neo $2010 \quad 06 \quad 572$

[9] CHANGXIN S, LIHUA H, LIN X AND YIRONG L: The detection of circulating tumor cells of breast cancer patients by using multimarker (Survivin, hTERT and hMAM) quantitative real-time PCR. Clin Biochem 2009; 42: 194-200. http:// dx.doi.org/10.1016/j.clinbiochem.2008.10.016

[10] CARMELIET P AND JAIN RK: Molecular mechanisms and clinical applications of angiogenesis. Nature 2011; 473: 298-307. http://dx.doi.org/10.1038/nature10144 
[11] FERRARA N, GERBER HP AND LECOUTER J: The biology of VEGF and its receptors. Nat Med 2003; 9: 669-676. http:// dx.doi.org/10.1038/nm0603-669

[12] LICHTENBERGER BM, TAN PK, NIEDERLEITHNER H, FERRARA N, PETZELBAUER P et al: Autocrine VEGF signaling synergizes with EGFR in tumor cells to promote epithelial cancer development. Cell 2010; 140: 268-279. http:// dx.doi.org/10.1016/j.cell.2009.12.046

[13] SHIVAKUMARS, PRABHAKAR BT, JAYASHREE K, RAJAN MG AND SALIMATH BP: Evaluation of serum vascular endothelial growth factor (VEGF) and microvessel density (MVD) as prognostic indicators in carcinoma breast. J Cancer Res Clin Oncol 2009; 135: 627-636. http://dx.doi.org/10.1007/ $\underline{\text { s00432-008-0497-9 }}$

[14] KIM S, OH SJ, LEE J, HAN J, JEON M et al: Berberine suppresses TPA-induced fibronectin expression through the inhibition of VEGF secretion in breast cancer cells. Cell Physiol Biochem 2013; 32: 1541-1550. http://dx.doi. org/10.1159/000356591

[15] HICKLIN DJ AND ELLIS LM: Role of the vascular endothelial growth factor pathway in tumor growth and angiogenesis. J Clin Oncol 2005; 23: 1011-1027. http://dx.doi.org/10.1200/ LCO.2005.06.081

[16] TANG XP, LI J, YU LC, CHEN YC, SHI SB et al: Clinical significance of survivin and VEGF mRNA detection in the cell fraction of the peripheral blood in non-small cell lung cancer patients before and after surgery. Lung Cancer 2013; 81: 273-279. http://dx.doi.org/10.1016/j. lungcan.2013.05.005

[17] ADAMKOV M, KAJO K, VYBOHOVA D, KRAJCOVIC J, STULLER F et al: Correlations of survivin expression with clinicomorphological parameters and hormonal receptor status in breast ductal carcinoma. Neoplasma 2012; 59: 30-37. http://dx.doi.org/10.4149/neo 2012004

[18] XU C, YAMAMOTO-IBUSUKI M, YAMAMOTO Y, YAMAMOTO S, FUJIWARA $S$ et al: High survivin mRNA expression is a predictor of poor prognosis in breast cancer: a comparative study at the mRNA and protein level. Breast Cancer 2012.

[19] WANG L-H, WANG B, LI L-H, ZHAN L AND ZHANG Z: Relationship between expressions of VEGF, MMP-9, COX-2 and lymph node metastasis and angiogenesis in breast carcinoma [J]. Chinese Journal of Clinical and Experimental Pathology 2008; 2: 010.

[20] GOKSEL G, TANELI F, USLU R, ULMAN C, DiNC G et al: Serum her-2/neu and survivin levels and their relationship to histological parameters in early-stage breast cancer. J Int Med Res 2007; 35: 165-172. http://dx.doi. org/10.1177/147323000703500201

[21] HODOROWICZ-ZANIEWSKA D, KIBIL W, MALEK A, SZPOR J, KULIG J et al: Evaluation of serum concentrations of vascular endothelial growth factor (VEGF) in breast cancer patients. Pol J Pathol 2012; 63: 255-260. http://dx.doi. org/10.5114/pjp.2012.32773

[22] SETOYAMA T, NATSUGOE S, OKUMURA H, MATSUMOTO M, UCHIKADO Y et al: Carcinoembryonic antigen messenger RNA expression in blood predicts re- currence in esophageal cancer. Clin Cancer Res 2006; 12: 5972-5977. http://dx.doi.org/10.1158/1078-0432.CCR-06$\underline{0637}$

[23] BUSTIN SA AND MUELLER R: Real-time reverse transcription PCR ( $\mathrm{qRT}-\mathrm{PCR}$ ) and its potential use in clinical diagnosis. Clin Sci (Lond) 2005; 109: 365-379. http://dx.doi.org/10.1042/ CS20050086

[24] KOGOVSEK P, GOW L, POMPE-NOVAK M, GRUDEN K, FOSTER GD et al: Single-step RT real-time PCR for sensitive detection and discrimination of Potato virus $\mathrm{Y}$ isolates. J Virol Methods2008; 149: 1-11. http://dx.doi.org/10.1016/j. jviromet.2008.01.025

[25] BREMNES RM, SIRERA R AND CAMPS C: Circulating tumour-derived DNA and RNA markers in blood: a tool for early detection, diagnostics, and follow-up? Lung Cancer 2005; 49: 1-12. http://dx.doi.org/10.1016/j. lungcan.2004.12.008

[26] MARCH-VILLALBA JA, MARTINEZ-JABALOYAS JM, HERRERO MJ, SANTAMARIA J, ALINO SF et al: Plasma hTERT mRNA discriminates between clinically localized and locally advanced disease and is a predictor of recurrence in prostate cancer patients. Expert Opin Biol Ther 12 Suppl 1: 2012; S69-77. http://dx.doi.org/10.1517/14712598.2012.685716

[27] ALTIERI DC: Targeting survivin in cancer. Cancer Lett 2013; 332: 225-228. http://dx.doi.org/10.1016/j.canlet.2012.03.005

[28] CHEUNG CH, CHENG L, CHANG KY, CHEN HH AND CHANG JY: Investigations of survivin: the past, present and future. Front Biosci (Landmark Ed) 2011; 16: 952-961. http:// dx.doi.org/10.2741/3728

[29] KU JH, GODOY G, AMIEL GE AND LERNER SP: Urine survivin as a diagnostic biomarker for bladder cancer: a systematic review. BJU Int 2012; 110: 630-636. http://dx.doi. org/10.1111/j.1464-410X.2011.10884.X

[30] SANTARELLI A, MASCITTI M, LO RUSSO L, COLELLA G AND GIANNATEMPO G: Detection Level of Salivary Survivin in Patients with OSCC. J Carcinogene Mutagene 2013; S 5: 29-85.

[31] LI J, LI ZN, BAO QL, GE LP, LI XQ et al: Evaluation of pleural fluid survivin and XIAP for the diagnosis of malignant pleural effusion. Tumour Biol 2012; 33: 1803-1810. http://dx.doi. org/10.1007/s13277-012-0439-7

[32] YIE SM, LUO B, YE NY, XIE K AND YE SR: Detection of Survivin-expressing circulating cancer cells in the peripheral blood of breast cancer patients by a RT-PCR ELISA. Clin Exp Metastasis 2006; 23: 279-289. http://dx.doi.org/10.1007/ $\underline{\text { s10585-006-9037-7 }}$

[33] GUNEY N, SOYDINE HO, DERIN D, TAS F, CAMLICA H et al: Serum and urine survivin levels in breast cancer. Med Oncol 2006; 23: 335-339. http://dx.doi.org/10.1385/MO:23:3:335

[34] MORIAI R, ASANUMA K, KOBAYASHI D, YAJIMA T, YAGIHASHI A ET AL: Quantitative analysis of the anti-apoptotic gene survivin expression in malignant haematopoietic cells. Anticancer Res 2001; 21: 595-600.

[35] MEHES G, WITT A, KUBISTA E AND AMBROS PF: Circulating breast cancer cells are frequently apoptotic. Am J Pathol 2001; 159: 17-20. http://dx.doi.org/10.1016/S00029440(10)61667-7 
[36] POON RT, FAN ST AND WONG J: Clinical implications of circulating angiogenic factors in cancer patients. J Clin Oncol 2001; 19: 1207-1225.

[37] DITTADI R, MEO S, FABRIS F, GASPARINI G, CONTRI $D$ et al: Validation of blood collection procedures for the determination of circulating vascular endothelial growth factor (VEGF) in different blood compartments. Int J Biol Markers 2001; 16: 87-96.

[38] PANDE D, NEGI R, KHANNA S, KHANNA R AND KHANNA HD: Vascular endothelial growth factor levels in relation to oxidative damage and antioxidant status in patients with breast cancer. J Breast Cancer 2011; 14: 181-184. http:// dx.doi.org/10.4048/jbc.2011.14.3.181

[39] THIELEMANN A, BASZCZUK A, KOPCZYNSKI Z, KOPCZYNSKI P and GRODECKA-GAZDECKA S: Clinical usefulness of assessing VEGF and soluble receptors sVEGFR-1 and sVEGFR-2 in women with breast cancer. Ann Agric Environ Med 2013; 20: 293-297.

[40] DE PAOLA F, GRANATO AM, SCARPI E, MONTI F, MEDRI L et al: Vascular endothelial growth factor and prognosis in patients with node-negative breast cancer. Int J Cancer 2002; 98: 228-233. http://dx.doi.org/10.1002/ ijc. 10118

[41] GRANATO AM, NANNI O, FALCINI F, FOLLI S, MOSCONI $\mathrm{G}$ et al: Basic fibroblast growth factor and vascular endothelial growth factor serum levels in breast cancer patients and healthy women: useful as diagnostic tools? Breast Cancer Res 2004; 6: R38-45. http://dx.doi.org/10.1186/bcr745

[42] SANCAK B, COSKUN U, GUNEL N, ONUK E, CIHAN A et al: No association between serum levels of insulin-like growth factor-I, vascular endothelial growth factor, prolactin and clinicopathological characteristics of breast carcinoma after surgery. Intern Med J 2004; 34: 310-315. http://dx.doi. org/10.1111/j.1444-0903.2004.00591.x

[43] SRABOVIC N, MUJAGIC Z, MUJANOVIC-MUSTEDANAGIC J, SOFTIC A, MUMINOVIC Z ET AL: Vascular endothelial growth factor receptor-1 expression in breast cancer and its correlation to vascular endothelial growth factor a. Int J Breast Cancer 2013; 746749. http://dx.doi. $\underline{\text { org } / 10.1155 / 2013 / 746749}$
[44] DVORAK HF, BROWN LF, DETMAR M AND DVORAK AM: Vascular permeability factor/vascular endothelial growth factor, microvascular hyperpermeability, and angiogenesis. Am J Pathol 1995; 146: 1029-1039.

[45] WARTIOVAARA U, SALVEN P, MIKKOLA H, LASSILA $\mathrm{R}, \mathrm{KAUKONEN} \mathrm{J} \mathrm{et} \mathrm{al:} \mathrm{Peripheral} \mathrm{blood} \mathrm{platelets} \mathrm{express}$ VEGF-C and VEGF which are released during platelet activation. Thromb Haemost 1998; 80: 171-175.

[46] MOHLE R, GREEN D, MOORE MA, NACHMAN RL AND RAFII S: Constitutive production and thrombin-induced release of vascular endothelial growth factor by human megakaryocytes and platelets. Proc Natl Acad Sci U S A 1997; 94: 663-668. http://dx.doi.org/10.1073/pnas.94.2.663

[47] SALVEN P, HEIKKILA P, ANTTONEN A, KAJANTI M AND JOENSUU H: Vascular endothelial growth factor in squamous cell head and neck carcinoma: expression and prognostic significance. Mod Pathol 1997; 10: 1128-1133.

[48] FREEMAN MR, SCHNECK FX, GAGNON ML, CORLESS C, SOKER S et al: Peripheral blood T lymphocytes and lymphocytes infiltrating human cancers express vascular endothelial growth factor: a potential role for T cells in angiogenesis. Cancer Res 1998; 55: 4140-4145.

[49] WERTHER K, CHRISTENSEN IJ AND NIELSEN HJ: Determination of vascular endothelial growth factor (VEGF) in circulating blood: significance of VEGF in various leucocytes and platelets. Scand J Clin Lab Invest 2002; 62: 343-350. http:// dx.doi.org/10.1080/00365510260296492

[50] SALVEN P, ORPANA A AND JOENSUU H: Leukocytes and platelets of patients with cancer contain high levels of vascular endothelial growth factor. Clin Cancer Res 1999; 5: 487-499.

[51] TRAN J, RAK J, SHEEHAN C, SAIBIL SD, LACASSE E et al: Marked induction of the IAP family antiapoptotic proteins survivin and XIAP by VEGF in vascular endothelial cells. Biochem Biophys Res Commun 1999; 264: 781-788. http:// dx.doi.org/10.1006/bbrc.1999.1589

[52] WANG P, ZHEN H, ZHANG J, ZHANG W, ZHANG R et al: Survivin promotes glioma angiogenesis through vascular endothelial growth factor and basic fibroblast growth factor in vitro and in vivo. Mol Carcinog 2012; 51: 586-595. http:// dx.doi.org/10.1002/mc.20829 


\title{
Supplementary Information
}

\section{Clinical significance of survivin and vascular endothelial growth factor mRNA detection in the peripheral whole blood of breast cancer patients}

\author{
S. WANG, J. XU, Q. ZHANG*
}

Key Laboratory of Carcinogenesis and Translational Research (Ministry of Education), Department of Clinical Laboratory, Peking University School of Oncology, Beijing Cancer Hospital \& Institute, Beijing 100142, China

*Correspondence: zhqy_208@163.com

\section{Supplement Figures}

Amplification curves of $\beta$-actin (Supplement Figure 1), Survivin (Supplement Figure 2) and VEGF (Supplement Figure 3) with flat baseline, distinct exponential area, large and stable slope.

Melt curves of $\beta$-actin (Supplement Figure 4), Survivin (Supplement Figure 5) and VEGF (Supplement Figure 6) with single homogeneous peak for all sample reactions which confirms specific amplification, so the data are reliable and meaningful for analysis and interpretation.

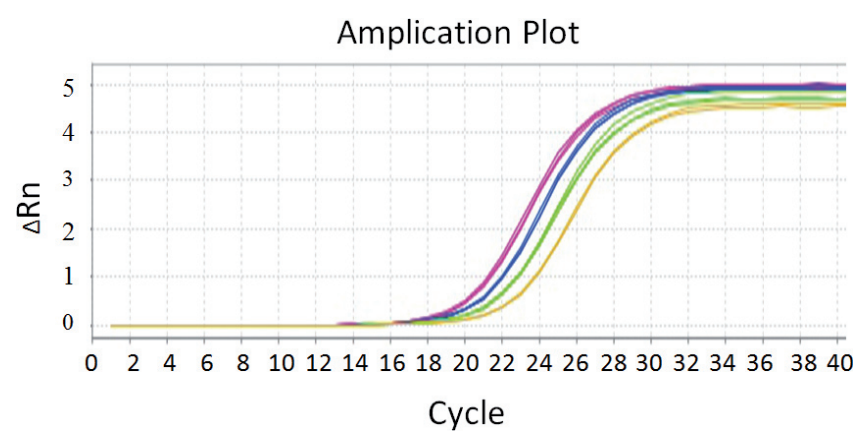

Supplement Figure 1

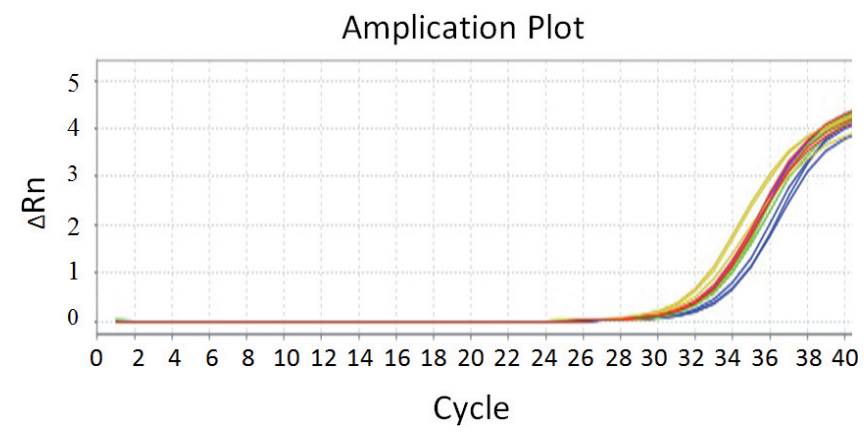

Supplement Figure 2

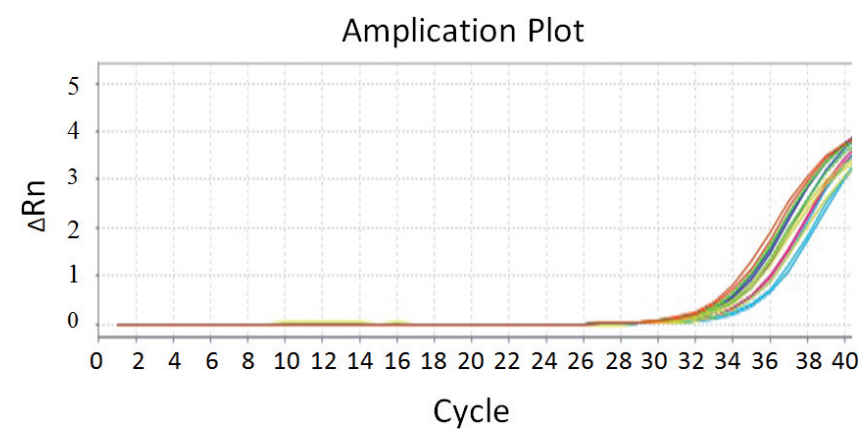

Supplement Figure 3 


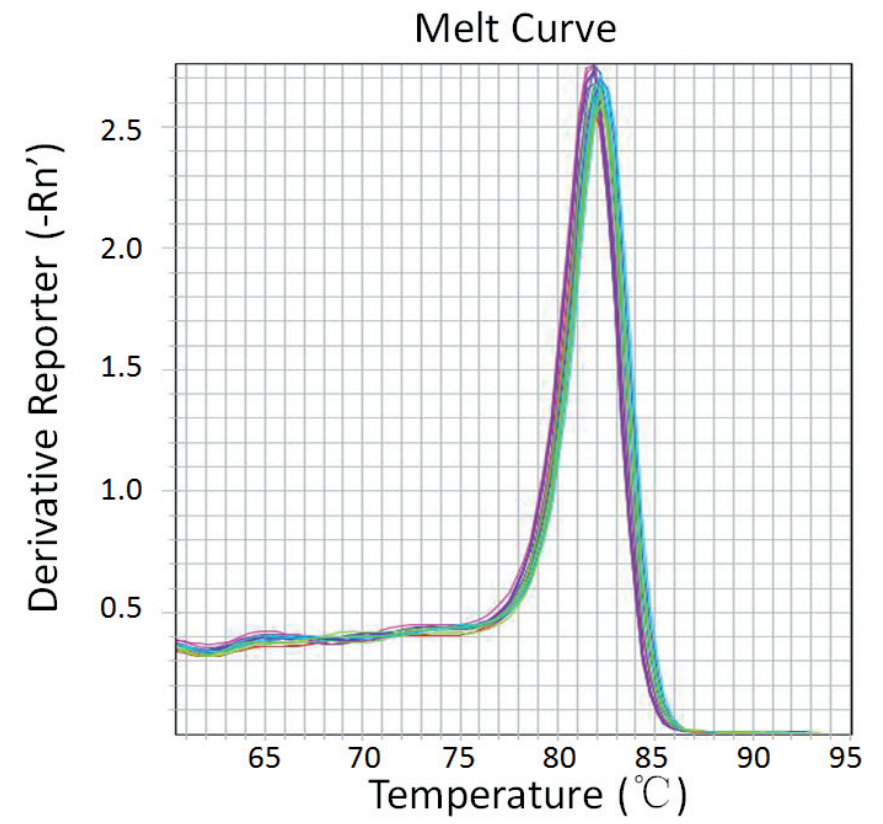

Supplement Figure 4

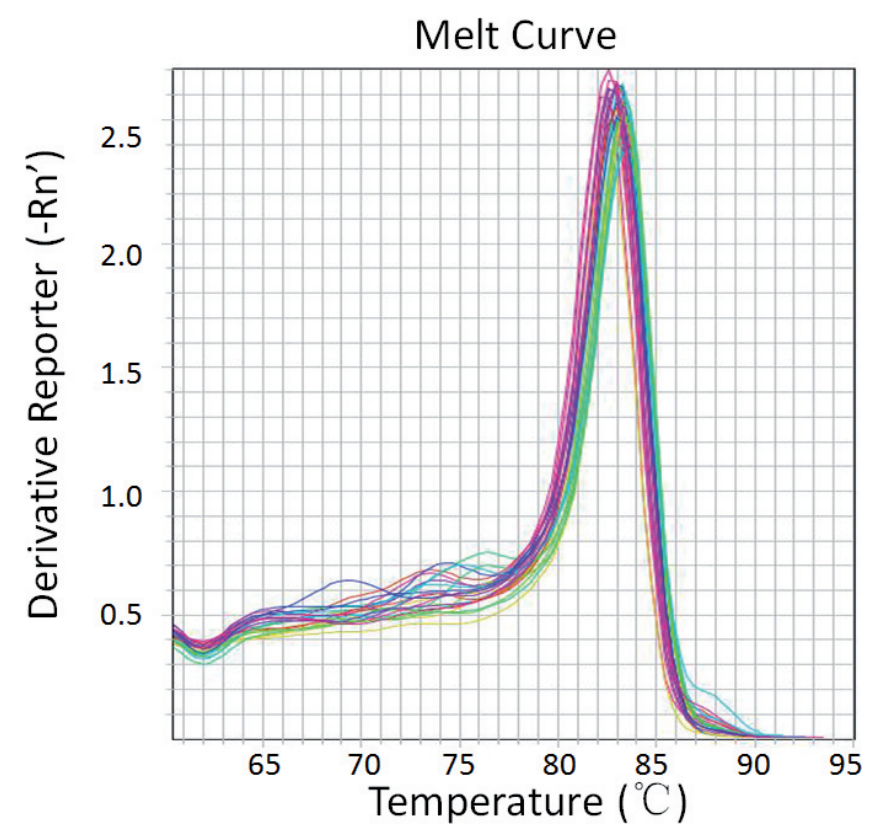

Supplement Figure 5

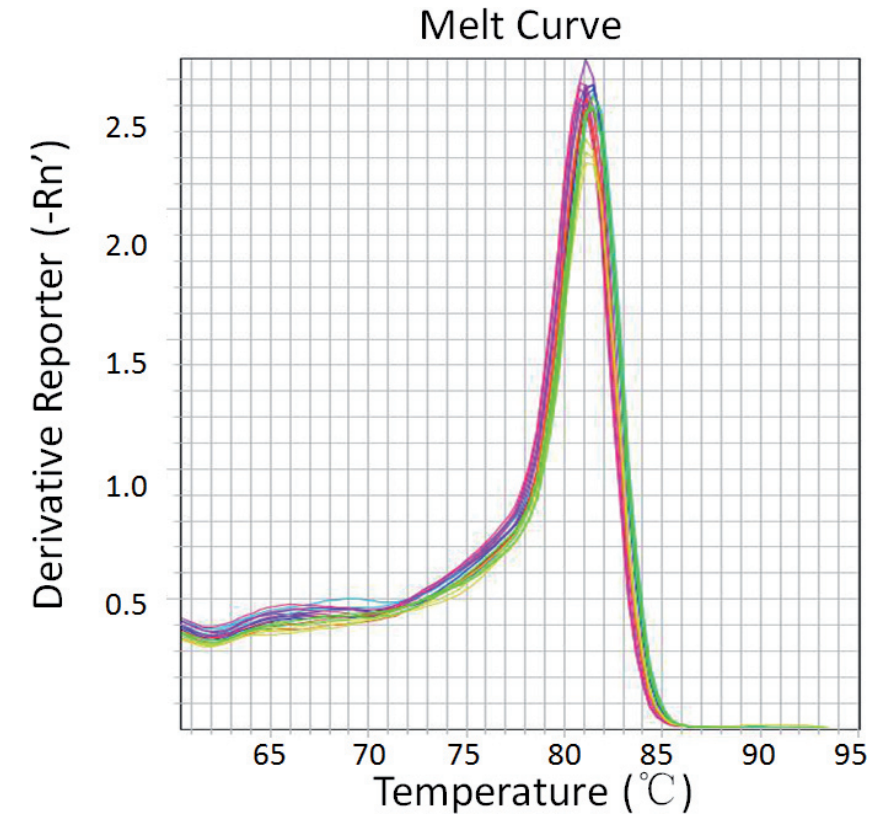

Supplement Figure 6 